\begin{tabular}{rlrr}
\hline \hline Volume: & 2 & E-ISSN: & $2655-1942$ \\
Number: & 2 & Terbitan: & Oktober 2019 \\
Page $:$ & $118-134$ & & \\
\hline
\end{tabular}

\title{
Aspek Hukum Pemberian Corporate Social Responsibilty Perusahaan Terhadap Lingkungan Sekitar
}

\author{
Bagus Rahmanda, Rinitami Njatrijani \\ Fakultas Hukum, Universitas Diponegoro \\ Jl. Prof. Soedarto, S.H. Tembalang, Semarang, Jawa Tengah 50275 \\ Koresprodensi: rahmandabagus@gmail.com
}

\begin{abstract}
Abstrak
Corporate Social Responsibilty merupakan bentuk kontribusi dan tanggungjawab perusahaan terhadap lingkungan sekitar dan bertujuan pembangunan berkelanjutan dengan cara manajemen terhadap seluruh pemangku kepentingannya. Penelitian ini bertujuan untuk; mengetahui dan menganalisis Aspek Hukum Perusahaan dalam pemberian Corporate Social Responsibility bagi lingkungan sekitar dan mengetahui Tinjauan Yuridis mengenai Corporate Social Responsibility di Indonesia Metode penelitian yuridis normatif. Yaitu suatu pendekatan yang mengacu pada hukum dan peraturan perundang-undangan yang berlaku. Berdasarkan hasil penelitian, operasi bisnis yang berkomitmen tidak hanya untuk meningkatkan keuntungan perusahaan secara finansial, tetapi untuk pembangunan sosial-ekonomi kawasan secara holistik, melembaga, dan berkelanjutan. Dengan adanya ketentuan kewajiban menjalankan CSR bagi perusahaan di Indonesia, perusahaan tidak hanya diharapkan pada tanggung jawab Single Bottom Line, yaitu tanggung jawab pada kondisi finansial perusahaan saja, tapi perusahaan juga dihadapkan pada tanggung jawab Triple Bottom Lines.
\end{abstract}

Kata Kunci: Aspek Hukum,Tanggungjawab Sosial Perusahaan, Lingkungan

\begin{abstract}
Corporate Social Responsibility is a form of company contribution and responsibility to the surrounding environment and aims at sustainable development by way of management of all its stakeholders. This research aims to; knowing and analyzing the Company's Legal Aspects in providing Corporate Social Responsibility to the surrounding environment and knowing Juridical Review of Corporate Social Responsibility in Indonesia Normative juridical research methods. That is an approach that refers to the laws and regulations in force. Based on the research results, business operations are committed not only to increasing the company's profitability financially, but to the socio-economic development of the region in a holistic, institutionalized and sustainable manner. With the provisions of the obligation to run CSR for companies in Indonesia, the company is not only expected to be responsible for the Single Bottom Line, which is the responsibility for the company's financial condition, but the company is also faced with the responsibility of Triple Bottom Lines.
\end{abstract}

Keyword: Legal Aspects, Corporate Social Responsibility, Environment 


\begin{tabular}{rlrr}
\hline \hline Volume: & 2 & E-ISSN: & $2655-1942$ \\
Number: & 2 & Terbitan: & Oktober 2019 \\
Page $:$ & $118-134$ & & \\
\hline
\end{tabular}

\section{A. Latar Belakang Masalah}

Pembangunan suatu negara bukan hanya tanggung jawab pemerintah saja, setiap insan manusia berperan untuk mewujudkan kesejahteraan sosial dan peningkatan kualitas hidup masyarakat. Dunia usaha berperan untuk mendorong pertumbuhan ekonomi yang sehat dengan mempertimbangan pula faktor lingkungan hidup. Kini dunia usaha tidak lagi hanya memperhatikan catatan keuangan perusahaan semata (single bottom line), melainkan sudah meliputi aspek keuangan, aspek sosial, dan aspek lingkungan biasa disebut triple bottom line. Dunia usaha perlu mencari pola-pola kemitraan (partnership) dengan seluruh stakeholder agar dapat berperan dalam pembangunan, sekaligus meningkatkan kinerjanya agar tetap dapat bertahan dan bahkan berkembang. Upaya tersebut secara umum dapat disebut sebagai Corporate Social Responsibility (CSR) atau corporate citizenship dan dimaksudkan untuk mendorong dunia usaha lebih etis dalam menjalankan aktivitasnya agar tidak berpengaruh atau berdampak buruk pada masyarakat dan lingkungan hidupnya, sehingga pada akhirnya dunia usaha akan dapat bertahan secara berkelanjutan untuk memperoleh manfaat ekonomi yang menjadi tujuan dibentuknya dunia usaha. Tanggung Jawab Sosial Korporasi / Corporate Social Responsibility (CSR) telah menjadi pemikiran para pembuat kebijakan sejak lama. Bahkan dalam Kode Hammurabi (1700-an SM) yang berisi 282 hukum telah memuat sanksi bagi para pengusaha yang lalai dalam menjaga kenyamanan warga atau menyebabkan kematian bagi pelanggannya. Dalam Kode Hammurabi disebutkan bahwa hukuman mati diberikan kepada orang-orang yang menyalahgunakan ijin penjualan minuman, pelayanan yang buruk dan melakukan pembangunan gedung di bawah standar sehingga menyebabkan kematian orang lain.

Penelitian sebelumnya yang terkait dengan penelitian saat ini adalah Pujiyono, Jamal Wiwoho dan Triyanto dengan fokus penelitian terhadap pertanggungjawaban Hukum terhadap pelaksanaan Corporate Social Responsibility (Yustisia, 2016). Penelitian sebelmya yang juga terkait dengan Corporate Social Responsibilty adalah Ade Yuliany Siahaan, Suhaidi, Sunarmi, dan Jelly Leviza dengan fokus pada Peran Pemerintah dalam pelaksanan CSR Perusahaan (USU Law Jurnal, 2018). Walapun penelitian saat ini dan penelitian sebelumnya sama-sama terkait dengan Corporate Social Responsibility terhadap lingkungan sekitar perusahaan namun fokus penelitian saat ini adalah bagaimana aspek hukum dan 


\begin{tabular}{rlrr}
\hline \hline Volume: & 2 & E-ISSN: & $2655-1942$ \\
Number: & 2 & Terbitan: & Oktober 2019 \\
Page : & $118-134$ & & \\
\hline
\end{tabular}

tinjauan yuridis terhadap pelaksanaan Corporate Social Responsibilty perusahaan terhadap lingkungan sekitar perusahaan tersebut. Mengingat belum adanya penelitian tentang hal ini maka menjadi hal penting dan aktual untuk dilakukan penelitian dan pengkajian.

Secara umum, perhatian para pembuat kebijakan terhadap CSR saat ini telah menunjukkan adanya kesadaran bahwa terdapat potensi timbulnya dampak buruk dari suatu kegiatan usaha. Dampak buruk tersebut tentunya harus direduksi sedemikian rupa sehingga tidak membahayakan kemaslahatan masyarakat sekaligus tetap bersifat kondusif terhadap iklim usaha. Konsep dan praktik CSR sudah menunjukkan gejala baru sebagai keharusan yang realistis diterapkan. Para pemilik modal tidak lagi menganggap CSR sebagai pemborosan. Masyarakat pun menilai hal tersebut sebagai suatu yang perlu, ini terkait dengan meningkatnya kesadaran sosial kemanusiaan dan lingkungan. Adapun mengenai rumusan masalah pada artikel ini adalah sebagai berikut :

1. Bagaimana Aspek Hukum Perusahaan dalam pemberian Corporate Social Responsibility bagi lingkungan sekitar?

2. Bagaimana Tinjauan Yuridis mengenai Corporate Social Responsibility di Indonesia?

Adapun Tujuan Penulisan ini adalah :

1. Mengetahui Aspek Hukum Perusahaan dalam pemberian Corporate Social Responsibility bagi lingkungan sekitar.

2. Mengetahui Tinjauan Yuridis mengenai Corporate Social Responsibility di Indonesia.

\section{B. Metode Penelitian}

Metode pendekatan yang digunakan dalam penelitian ini adalah pendekatan yuridis normatif. Yaitu suatu pendekatan yang mengacu pada hukum dan peraturan perundangundangan yang berlaku. Dalam penelitian ini digunakan spesifikasi penelitian secara deskriptif analitis. Deskriptif, yaitu penelitian yang bertujuan melukiskan tentang suatu hal di daerah tertentu dan pada saat tertentu. ${ }^{1}$

Penelitian ini menggunakan sumber data kepustakaan. Jenis datanya adalah data sekunder yaitu data yang diperoleh melalui bahan pustaka dengan cara mengumpulkan dari

\footnotetext{
${ }^{1}$ Priyono, Ery Agus, Bahan Kuliah Metodologi Penelitian, Program Studi Magister Kenotariatan Universitas Diponegoro, Semarang, 2003/2004
} 


\begin{tabular}{llrr}
\hline \hline Volume: & 2 & E-ISSN: & $2655-1942$ \\
Number: & 2 & Terbitan: & Oktober 2019 \\
Page : $118-134$ & & \\
\hline
\end{tabular}

berbagai sumber bacaan yang berhubungan dengan masalah yang diteliti. Analisis yang digunakan dalam penelitian ini menggunakan analisis kualitatif, yaitu menganalisis data yang berupa bahan-bahan hukum dan bahan-bahan pustaka. Analisis dilakukan dengan penafsiran terhadap data hasil penelitian. Hasil analisis disajikan secara sederhana dan sistematis.

\section{Hasil Penelitian dan Pembahasan}

1. Aspek Hukum Perusahaan Dalam Pemberian Corporate Social Responsibily Bagi Lingkungan Sekitar

Istilah CSR pertama kali menyeruak dalam tulisan Social Responsibility of the Businessman tahun 1953. Konsep yang digagas Howard Rothmann Browen ini menjawab keresahan dunia bisnis. Belakangan CSR segera diadopsi, karena bisa jadi penawar kesan buruk perusahaan yang terlanjur dalam pikiran masyarakat dan lebih dari itu pengusaha di cap sebagai pemburu uang yang tidak peduli pada dampak kemiskinan dan kerusakan lingkungan. Kendati sederhana, istilah CSR amat marketable melalu CSR pengusaha tidak perlu diganggu perasaan bersalah. CSR merupakan tanggung jawab aktivitas sosial kemasyarakatan yang tidak berorientasi profit. John Elkington dalam buku "Triple Bottom Line" dengan 3P tipe yaitu:

- Profit mendukung laba perusahaan

- People meningkatkan kesejahteraan masyarakat

- Planet meningkatkan kualitas lingkungan

Pengertian CSR sangat beragam. Intinya, CSR adalah operasi bisnis yang berkomitmen tidak hanya untuk meningkatkan keuntungan perusahaan secara finansial, tetapi untuk pembangunan sosial-ekonomi kawasan secara holistik, melembaga, dan berkelanjutan. Beberapa nama lain yang memiliki kemiripan dan bahkan sering diidentikkan dengan CSR adalah corporate giving, corporate philanthropy, corporate community relations, dan community development. CSR berhubungan erat dengan "pembangunan berkelanjutan", yakni suatu organisasi, terutama perusahaan, dalam melaksanakan aktivitasnya harus 


\begin{tabular}{rlrr}
\hline \hline Volume: & 2 & E-ISSN: & $2655-1942$ \\
Number: & 2 & Terbitan: & Oktober 2019 \\
Page : & $118-134$ & & \\
\hline
\end{tabular}

mendasarkan keputusannya tidak semata berdasarkan dampaknya $\mathrm{d}^{2}$ alam aspek ekonomi, misalnya tingkat keuntungan atau deviden, tetapi juga harus menimbang dampak sosial dan lingkungan yang timbul dari keputusannya itu, baik untuk jangka pendek maupun untuk jangka yang lebih panjang. Dengan pengertian tersebut, CSR dapat dikatakan sebagai kontribusi perusahaan terhadap tujuan pembangunan berkelanjutan dengan cara manajemen dampak (minimisasi dampak negatif dan maksimisasi dampak positif) terhadap seluruh pemangku kepentingannya. ${ }^{3}$

Ditinjau dari motivasinya, keempat nama itu bisa dimaknai sebagai dimensi atau pendekatan CSR. Jika corporate giving bermotif amal atau charity, corporate philanthropy bermotif kemanusiaan dan corporate community relations bernapaskan tebar pesona, community development lebih bernuansa pemberdayaan.

Dalam konteks global, istilah CSR mulai digunakan sejak tahun 1970-an dan semakin populer terutama setelah kehadiran buku Cannibals with Forks: The Triple Bottom Line in 21st Century Business (1998) karya John Elkington. Mengembangkan tiga komponen penting sustainable development, yakni economic growth, environmental protection, dan social equity yang digagas the World Commission on Environment and Development (WCED) dalam Brundtland Report (1987), Elkington mengemas CSR ke dalam tiga fokus: 3P (profit, planet, dan people). Perusahaan yang baik tidak hanya memburu keuntungan ekonomi belaka (profit), tetapi memiliki kepedulian terhadap kelestarian lingkungan (planet) dan kesejahteraan masyarakat ${ }^{3}$.

Setidaknya ada 2 (dua) landasan berkenaan dengan corporate social responsibility (CSR) yaitu berasal dari etika bisnis (bisa berdasarkan agama, budaya atau etika kebaikan lainnya) dan dimensi sosial dari aktivitas bisnis. CSR atau sering diartikan sebagai "being socially responsible" jelas merupakan suatu cara-cara yang berbeda untuk orang yang berbeda dalam negara yang berbeda pula. Artinya penerapan CSR di masing-masing negara harus disesuaikan dengan konteks sosial dan lingkungannya. Sehingga perlu kehati-hatian dalam menerapkan konsep CSR dari negara-negara maju di negara-negara yang sedang

\footnotetext{
${ }^{2}$ Wikipedia, (Diakses melalui https://id.wikipedia.org/wiki/Tanggung_jawab_sosial_perusahaan pada 11 Agustus 2019)

${ }^{3}$ Subari, 2014, "Corporate Social Responsibility” (Diakses melalui

http://subaripemuda.blogspot.com/2015/01/makalah-tentang-corporate-social.html pada 11 Agustus 2019)
} 


\begin{tabular}{llrr}
\hline \hline Volume: & 2 & E-ISSN: & $2655-1942$ \\
Number: & 2 & Terbitan: & Oktober 2019 \\
Page : $118-134$ & & \\
\hline
\end{tabular}

berkembang. ${ }^{4}$ Corporate social responsibility (CSR) merupakan bentuk kepedulian perusahaan terhadap lingkungannya. Kepedulian ini sudah menjadi kegiatan berbagai perusahaan besar internasional sejak lama, di Indonesia, istilah ini baru muncul belakangan meski sesungguhnya beberapa perusahaan sudah melakukan berbagai kegiatan yang termasuk ke dalam kategori CSR, sebelumnya, kini CSR semakin menjadi perhatian karena perusahaan kian percaya bahwa lingkungan punya pengaruh teramat besar terhadap keberlangsungan hidup mereka. Buku ini mengulas segala hal yang menyangkut CSR dan sekaligus menunjukkan contoh-contoh nyata bagaimana perusahaan di Indonesia melaksanakan program ini. ${ }^{5}$

Dalam UU No. 40 Tahun 2007 tentang Perseroan Terbatas dianggap sebagai "komitmen Perseroan" yang artinya lebih kepada sikap moral daripada kewajiban hukum. Perusahaan menjalankan tanggung jawab sosial (corporate social responsibility) bukan hanya untuk membantu pemerintah mewujudkan kesejahteraan sosial seluruh masyarakat, namun juga karena ada keuntungan yang didapatkan perusahaan, yaitu:

1. Perusahaan mendapatkan citra positif dari masyarakat, terutama dalam perusahaan go public yang memerlukan citra baik agar nilai sahamnya baik dan kompetitif;

2. Perusahaan dapat mewujudkan keberlanjutan (sustainability) perusahaan dan menghindari adanya konflik antara perusahaan dengan stakeholder. Perusahaan tidak dapat berjalan dengan baik jika tidak berhubungan baik dengan masyarakat. Keberlanjutan suatu perusahaan tidak hanya berkaitan dengan mencari laba semata. Selain berhubungan dengan masyarakat, perusahaan (bisnis) tidak bisa dipisahkan dengan peran pemerintah. Bisnis dan pemerintah adalah institusi yang bekerja dalam masyarakat. Individu dalam masyarakat secara konstan bergerak dan saling berinteraksi untuk menghadirkan perubahan. Maka antara pemerintah, bisnis, dan masyarakat saling memperngaruhi.

3. Perusahaan dapat memberikan kontribusi langsung bagi kelestarian lingkungan hidup di sekitar perusahaan berada. Menjaga kelestarian lingkungan hidup, secara langsung maupun tidak akan memberikan dampak positif pula kepada perusahaan. Lingkungan

\footnotetext{
${ }^{4}$ Meilanny Budiarti S, Santoso Tri Raharjo, 2014, “Corporate Social Responsibility (Csr) Dari Sudut Pandang Perusahaan" (Jurnal Universitas Padjajaran), hlm 25.

${ }^{5}$ Ambadar,Jackie, 2013, “Corporate Social Responsibility (CSR) Dalam Praktik di Indonesia,Jakarta, Balai Pustaka, hlm 4.
} 


\begin{tabular}{llrr}
\hline \hline Volume: & 2 & E-ISSN: & $2655-1942$ \\
Number: & 2 & Terbitan: & Oktober 2019 \\
Page : $118-134$ & & \\
\hline
\end{tabular}

yang rusak pasti akan menimbulkan kerugian. Menjaga kelestarian dan keberlanjutan lingkungan merupakan investasi jangka panjang karena kegiatan melestarikan lingkungan dapat menghemat biaya produksi suatu perusahaan. Sebagai contoh, banyak perusahaan yang mulai menghemat penggunaan air dan melakukan pengelolaan limbah dengan baik. Pengelolaan air dan limbah ini dapat mengurangi biaya yang ditanggung perusahaan sekaligus menjaga kelestarian lingkungan.

4. Perusahaan mendapatkan kesempatan untuk memperlihatkan kelebihan perusahaannya dibandingkan perusahaan pesaing. Dari Pembahasan di atas menjadi alasan mengapa tanggung jawab sosial perusahaan (corporate social responsibility) menjadi kewajiban hukum. ${ }^{6}$

Telah terjadi pergeseran kewajiban moral dan etika perusahaan dari tanggung jawab sosial perusahaan, menjadi kewajiban hukum. Apabila hukum tidak mencerminkan nilai moral, maka akan mengakibatkan suatu aturan hukum kehilangan substansinya menciptakan keadilan. $^{7}$

\section{Tinjauan Yuridis Corporate Social Responsibility di Indonesia}

Dalam kebijakannya pemerintah Indonesia telah mengatur mengenai tanggungjawab sosial perusahaan yang salah satunya diatur dalam Undang-Undang Nomor 40 Tahun 2007 Tentang Perseroan Terbatas. Disebutkan bahwa dalam Pasal 74 ayat (1) Undang-Undang Nomor 40 Tahun 2007 adalah : "Perseroan yang menjalankan kegiatan usahanya di bidang dan/atau berkaitan dengan sumber daya alam wajib melaksanakan Tanggung Jawab Sosial dan Lingkungan."

Ayat (2)

"Tanggung Jawab Sosial dan Lingkungan sebagaimana dimaksud pada ayat (1) merupakan kewajiban Perseroan yang dianggarkan dan diperhitungkan sebagai biaya Perseroan yang pelaksanaannya dilakukan dengan memperhatikan kepatutan dan kewajaran."

\footnotetext{
${ }^{6}$ Dewa Ayu Putu Shandra Dewi,I Nyoman Nurjana,Sihabudin "Kewajiban Hukum Tanggung Jawab Sosial Perusahaan (CSR) Dalam Peraturan Perundang-Unadangan di Indonesia", Jurnal Magister Kenotariatan Fakultas Brawijaya, diakses 20 September 2019.

${ }^{7}$ Mukti Fajar ND., Tanggung jawab Sosial Perusahaan di Indonesia: Studi tentang Penerapan Ketentuan CSR pada Perusahaan Multinasional, Swasta Nasional, dan BUMN di Indonesia, Pustaka Pelajar, Yogyakarta, 2010, hlm. 124-134, dalam Yeti Sumiyati, 2013, Peranan BUMN dalam Pelaksanaan Tanggung Jawab Sosial Perusahaan untuk Meningkatkan Kesejahteraan Rakyat, Jurnal Hukum IUS QUIA IUSTUM NO. 3 VOL. 20, Hlm. 466
} 


\begin{tabular}{llrr}
\hline \hline Volume: & 2 & E-ISSN: & $2655-1942$ \\
Number: & 2 & Terbitan: & Oktober 2019 \\
Page $:$ & $118-134$ & & \\
\hline
\end{tabular}

Ayat (3)

"Perseroan yang tidak melaksanakan kewajiban sebagaimana dimaksud pada ayat (1) dikenai sanksi sesuai dengan ketentuan peraturan perundang-undangan."

Ayat (4)

"Ketentuan lebih lanjut mengenai Tanggung Jawab Sosial dan Lingkungan diatur dengan Peraturan Pemerintah."

Dengan adanya ketentuan kewajiban menjalankan CSR bagi perusahaan di Indonesia, perusahaan tidak hanya diharapkan pada tanggung jawab Single Bottom Line, yaitu tanggung jawab pada kondisi finansial perusahaan saja, tapi perusahaan juga dihadapkan pada tanggung jawab Triple Bottom Lines, maksudnya adalah selain tanggung jawab finansial, perusahaan juga diharapkan kepada tanggung jawab lingkungan dan sosial. Karena kelangsungan perusahaan yang berkelanjutan (Sustaineble) tidak bisa hanya dilihat dari aspek finansial saja, tetapi perlu dilihat juga dari aspek sosial dan lingkungan sekitar perusahaan. ${ }^{8}$ Tanggungjawab sosial perusahaan atau Corporate Social Responsibility (CSR), diatur secara tegas di Indonesia, dalam Undang-Undang Nomor 40 Tahun 2007 tentang Perseroan Terbatas, terdapat empat alasan hukum mengenai perlunya CSR diatur dalam Perundang undangan di Indonesia. Keempat alas an hukum tersebut terdiri dari: ${ }^{9}$

1) Alasan Filosofis

Dalam rangka lebih meningkatkan pembangunan perekonomian nasional yang sekaligus memberikan landasan yang kokoh bagi dunia usaha dalam menghadapi perkembangan perekonomian di era globalisasi pada masa mendatang, perlu didukung oleh suatu undang-undang yang mengatur tentang perseroan terbatas yang dapat menjamin terselenggaranya iklim dunia usaha yang kondusif.

2) Alasan Historis

Semenjak keruntuhan rezim diktatoriat Orde Baru, masyarakat semakin berani untuk beraspirasi dan mengekspresikan tuntutannya terhadap perkembangan dunia bisnis Indonesia. Masyarakat telah semakin kritis dan mampu melakukan kontrol sosial

\footnotetext{
${ }^{8}$ Hendrik Budi Untung, Corporate Social Responsbility, Jakarta: Sinar Grafika, 2008, hal. 25.

${ }^{9}$ Ely Kusumardani, “Tinjauan Yuridis Corporate Social Responsibility (Csr) Menurut Undang-Undang Nomor 40 Tahun 2007 Tentang Perseroan Terbatas” (Surakarta: UMS, 2016), hlm 5-8
} 
terhadap dunia usaha. Hal ini menuntut para pelaku bisnis untuk menjalankan usahanya dengan semakin bertanggungjawab. Pelaku bisnis tidak hanya dituntut untuk memperoleh keuntungan dari lapangan usahanya, melainkan mereka juga diminta untuk memberikan kontribusi positif terhadap lingkungan sosialnya.

\section{3) Alasan Sosiologis}

Pada dasarnya pembentukan pengaturan terkait CSR juga tidak terlepas dari adanya teori stakeholders dan teori legitimasi. Dalam hal ini adanya pengaturan CSR dalam Undang-Undang Nomor 40 Tahun 2007 tentang Perseroan Terbatas, tidak terlepas peran dari pemerintah mencoba untuk mempertimbangkan kondisi stakeholders yang berada di sekitar perusahaan-perusahaan besar yang terdapat di Indonesia. Selain itu tidak mengherankan jika saat ini masyarakat resah, bahkan ketakutan akan dampak dan implikasi langsung yang ditimbulkan terhadap aktivitas perusahaan yang melakukan eksplorasi sumber daya alam. Hal tersebut juga dapat menimbulkan berbagai konsekuensi logis bagi masyarakat sekitarnya. Diantaranya adalah berubahnya struktur dan tatanan sosial ekonomi dan budaya masyarakat, kondisi fisik dan kerusakan lingkungan, serta beban psikologis dan trauma masyarakat sekitar.

4) Alasan Yuridis

Dengan situasi yang berkembang CSR memerlukan regulasi hukum yang tepat. Dalam Undang-Undang Nomor 1 Tahun 1995 tentang Perseroan Terbatas belum diatur mengenai CSR. Namun setelah tanggal 16 Agustus 2007, CSR di Indonesia telah diatur setelah diundangkannya Undang-Undang Nomor 40 tahun 2007 tentang Perseroan Terbatas (UUPT) yang menggantikan Undang-Undang Nomor 1 tahun 1995 tentang Perseroan Terbatas. Penerapan kegiatan CSR di Indonesia baru dimulai pada awal tahun 2000, walaupun kegiatan dengan esensi dasar yang sama telah berjalan sejak tahun 1970-an, dengan tingkat yang bervariasi, mulai dari yang paling sederhana seperti donasi sampai kepada yang komprehensif seperti terintegrasi ke dalam strategi perusahaan dalam mengoperasikan usahanya. Belakangan melalui Undang-Undang Nomor 40 Tahun 2007 tentang Perseroan Terbatas, Pemerintah memasukkan pengaturan Tanggung Jawab Sosial dan Lingkungan ke dalam Undang-Undang Perseroan Terbatas. 


\begin{tabular}{rlrr} 
Volume: & 2 & E-ISSN: & $2655-1942$ \\
Number: & 2 & Terbitan: & Oktober 2019 \\
Page $:$ & $118-134$ & & \\
\hline
\end{tabular}

Pasal 33 Undang-Undang Dasar Negara Kesatuan Republik Indonesia Tahun 1945, merupakan dasar bagi sistem perekonomian Indonesia. Berdasarkan ketentuan Pasal 33 ayat (1) Undang-Undang Dasar Negara Kesatuan Republik Indonesia Tahun 1945, "Perekonomian disusun sebagai usaha bersama berdasar atas asas kekeluargaan". Dalam Pasal 33 ayat (4) Undang-Undang Dasar Negara Kesatuan Republik Indonesia Tahun 1945, menyatakan: "Perekonomian nasional diselenggarakan berdasar asas demokrasi ekonomi dengan kebersamaan, efisiensi berkeadilan, berkelanjutan, berwawasan lingkungan, kemandirian, serta dengan menjaga keseimbangan kemajuan dan kesatuan ekonomi nasional". Pasal 33 Undang-Undang Dasar Negara Kesatuan Republik Indonesia Tahun 1945 merupakan landasan konstitusional dari UU No. 19 Tahun 2003 tentang Badan 7 Usaha Milik Negara, UU No. 25 Tahun 2007 tentang Penanaman Modal, UU No. 40 Tahun 2007 tentang Perseroan Terbatas, dan UU No. 4 Tahun 2009 tentang Pertambangan Mineral dan Batubara. Keempat undang-undang tersebut mewajibkan perusahaan melaksanakan tanggung jawab sosial perusahaan (corporate social responsibility). Diantara undang-undang tersebut, hanya UU No. 25 Tahun 2007 tentang Penanaman Modal yang menggunakan istilah "badan usaha". UU No. 40 Tahun 2007 tentang Perseroan Terbatas, mewajibkan tanggung jawab sosial perusahaan yang melakukan kegiatan usaha di bidang dan/atau berkaitan dengan sumber daya alam. Sedangkan UU No. 4 Tahun 2009 tentang Pertambangan Mineral dan Batubara menggunakan istilah badan usaha namun yang dimaksud adalah badan hukum yang bergerak di bidang pertambangan yang didirikan berdasarkan hukum Indonesia dan berkedudukan dalam wilayah Negara Kesatuan Republik Indonesia. Tanggung jawab sosial yang dimiliki perusahaan kepada masyarakat, seharusnya tidak hanya dilakukan oleh corporate dalam arti perusahaan yang bersifat badan hukum dan berskala besar saja. Tidak menutup kemungkinan perusahaan perseorangan yang belum berbadan hukum juga menimbulkan dampak sosial dan lingkungan yang signifikan bagi masyarakat di sekitarnya. Jika menggunakan istilah tanggung jawab sosial perusahaan, maka tanggung jawab sosial perusahaan tanpa memandang seberapa besarnya perusahaan tersebut. Di Indonesia, tanggung jawab sosial perusahaan (corporate social responsibility) menjadi suatu kewajiban hukum (legal mandatory). Menurut Dirk Matten dan Jeremy Moon, pelaksanaan tanggung jawab sosial perusahaan (corporate 


\begin{tabular}{llrr}
\hline \hline Volume: & 2 & E-ISSN: & $2655-1942$ \\
Number: & 2 & Terbitan: & Oktober 2019 \\
Page : $118-134$ & & \\
\hline
\end{tabular}

social responsibility) dapat dibedakan menjadi dua pendekatan, yaitu secara eksplisit dan implisit. Tanggung jawab sosial perusahaan yang eksplisit, dilakukan secara sukarela (voluntary), segala strategi, program, dan kebijakan perusahaan merupakan keinginan internal dari perusahaan sendiri. Perusahaan tersebut melaksanakan tanggung jawab sosial perusahaan sebagai suatu tanggung jawabnya kepada perusahaan dan seluruh pemangku kepentingannya. Sedangkan tanggung jawab sosial perusahaan yang implisit berarti, seluruh institusi negara baik formal maupun informal menugaskan 8 perusahaan untuk melaksanakan tanggung jawab sosial perusahaannya. Tanggung jawab sosial perusahaan yang implisit biasanya terdiri dari nilai-nilai, norma, dan peraturan yang menghasilkan (sebagian besar mandatory tetpi juga customary) sebagai persyaratan untuk mengingatkan perusahaan perihal pelaksanaan kewajiban perusahaan pada pemangku kepentingan (stakeholder).$^{10}$ Berdasarkan hal tersebut, maka Indonesia termasuk negara yang menjalankan penerapan tanggung jawab sosial perusahaan dengan pendekatan implisit. Isu mengenai tanggung jawab sosial perusahaan (corporate social responsibility) diatur dalam suatu peraturan perundang-undangan. Maka, tanggung jawab sosial perusahaan (corporate social responsibility) dapat dilakukan dengan beragam pendekatan, baik yang sifatnya sukarela maupun wajib (mandatory). ${ }^{11}$

\footnotetext{
${ }^{10}$ Matten, Dirk and Jeremy Moon, Implicit and Explisit CSR: A Conceptual Framework For Understanding CSR In Europe, https://www.nottingham.ac.uk/business/ICCSR/research.php?action=download\&id=51, diakses 20 September 2019.

11 Dewa Ayu Putu Shandra Dewi,I Nyoman Nurjana,Sihabudin "Kewajiban Hukum Tanggung Jawab Sosial Perusahaan (CSR) Dalam Peraturan Perundang-Unadangan di Indonesia", Jurnal Magister Kenotariatan Fakultas Brawijaya, diakses 20 September 2019.
} 


\begin{tabular}{llrr}
\hline \hline Volume: & 2 & E-ISSN: & $2655-1942$ \\
Number: & 2 & Terbitan: & Oktober 2019 \\
Page : $118-134$ & & \\
\hline
\end{tabular}

\section{Contoh Kasus:}

\section{CSR Sebagai Bentuk Komunikasi Kesehatan dan Lingkungan}

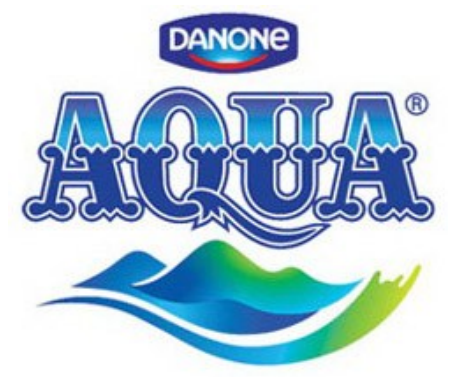

Danone Aqua melakukan program CSR yang disebut WASH (wash access, sanitation, hygiene program) yang bertujuan untuk meningkatkan kesejahteraan masyarakat prasejahtera dan berkontribusi secara aktif dan berkelanjutan untuk memberikan solusi terhadap masalah yang berkaitan dengan penyediaan air bersih di Indonesia. Program ini akrab dengan "1 liter Aqua untuk 10 liter air bersih". Program ini didasarkan pada fakta bahwa air merupakan kebutuhan mendasar bagi manusia, namun masalahnya tidak semua orang bisa mengakses air bersih, karena faktor yang membutuhkan infrastruktur yang memadai untuk itu. Dimana sebagai kesehatan lingkungan dan diri adalah sesuatu yang mahal dan harus dijaga oleh individu. Program ini dilaksanakan di Nusa Tenggara Timur (NTT), NTT dianggap sebagai daerah yang tepat, karena daerah tersebut mengalami kelangkaan air bersih. Masyarakat NTT juga masih kesulitan mengakses air bersih, mereka harus menempuh jarak yang cukup jauh, jalan yang curam, berbatu dan bahkan harus melewati sungai. Dibutuhkan waktu sekitar satu jam untuk mengambil dan membawa pulang air setiap harinya.

Berdasarkan permasalahan tersebut, Aqua berkomitmen untuk meningkatkan kesejahteraan masyarakat NTT. Untuk setiap pembelian Aqua 1 liter, maka konsumen telah membantu program Aqua dengan menyumbangkan 10 liter air bersih kepada masyarakat yang membutuhkan. Program "1 liter Aqua untuk 10 liter air bersih" ini telah berhasil memberikan dampak yang positif bagi bagi masyarakat di daerah Timor Tengah Selatan NTT. Sebelum implementasi program, waktu yang biasanya diperlukan oleh warga setempat untuk memperoleh air adalah sekitar satu jam, sekarang setelah program ini berjalan diperkirakan hanya membutuhkan waktu maksimali 20 menit. Dan jarak tempuh untuk 


\begin{tabular}{rlrr}
\hline \hline Volume: & 2 & E-ISSN: & $2655-1942$ \\
Number: & 2 & Terbitan: & Oktober 2019 \\
Page : & $118-134$ & & \\
\hline
\end{tabular}

memperoleh air sebelum program ini dilakukan adalah sekitar 1 kilometer dengan medan yang berbahaya, dan sekarang diperkirakan hanya berjarak 200 meter saja.

Selain itu, Aqua juga ikut memelihara sumber air bersama warga agar hasil dan manfaat dari program ini dapat berlangsung lama di dalam memenuhi kebutuhan air masyarakat setempat. Kemudian Aqua juga memberikan program penyuluhan pemanfaatan air untuk pola hidup sehat agar warga dapat memanfaatkan air seefisien mungkin dan dapat menggunakan air tersebut untuk memenuhi pola hidup sehat.

Dalam pelaksanaan program CSR Aqua "1 liter Aqua untuk 10 liter air bersih" ini, dapat dikatakan Aqua adalah perusahaan yang berbisinis secara etis atau beretika. Aqua dikatakan beretika karena dilihat dari program yang dilaksanakan, Aqua mencoba untuk melakukan hal benar sesuai dengan kebutuhan masyarakat, dan tidak hanya berorientasi pada hal finansial saja. Aqua menjalankan bisnisnya dengan etis karena memperhatikan tiga norma dalam etika berbisnis, yaitu:

a) Utility: Aqua memperhatikan segi kemanfaatan atas kegiatan yang dilakukannya. Aqua mendapatkan manfaat karena para konsumen tertarik berpartisipasi dalam program "1 liter Aqua untuk 10 liter air bersih" dengan melakukan pembelian Aqua. Sedangkan masyarakat NTT medapatkan kemanfaatkan dengan semakin dekatnya jarak tempuh untuk memperoleh air, dan dengan kemudahan untuk mendapatkan air bersih, maka kesehatan masyarakat NTT pun semakin membaik.

b) Rights : Aqua sebagai perusahaan yang memproduksi air mineral kemasan, mencoba untuk memenuhi hak-hak masyarakat NTT yang memiliki permasalahan dalam pemenuhan kebutuhan air bersih.

c) Justice : Aqua menyadari bahwa produk yang mereka produksi adalah air mineral yang merupakan sumber daya alam, sehingga program CSR yang dilakukan berorientasi pada pelestarian alam. Aqua mencoba untuk memberikan sebuah keadilan bagi masyarakat NTT dengan program tersebut, agar masyarakat NTT merasa diperlakukan adil layaknya masyarakat wilayah lain yang kebutuhan air bersihnya terpenuhi.

Dalam melaksanakan program CSR "1 liter Aqua untuk 10 liter air bersih", Aqua mengutamakan aspek yang berkelanjutan. Proram tersebut dipantau perkembangan dan 


\begin{tabular}{rlrr}
\hline \hline Volume: & 2 & E-ISSN: & $2655-1942$ \\
Number: & 2 & Terbitan: & Oktober 2019 \\
Page : & $118-134$ & & \\
\hline
\end{tabular}

tingkat keberhasilannya, kemudian program tersebut dilakukan secara continue dan berkesinambungan sehingga tidak hanya sekedar membahagiakan masyarakat secara instant dan sekejap. Program CSR "1 liter Aqua untuk 10 liter air bersih" masih terus berlanjut hingga sekarang, Aqua membantu wilayah-wilayah lain yang memiliki permasalahan dalam pemenuhan kebutuhan air bersih. Dari kegiatan CSR yang telah dilakukan oleh Aqua tersebut, dapat dikatakan bahwa Aqua cukup sukses dalam menjalankan program CSR-nya. Terbukti dari beberapa penghargaan yang telah diraih Aqua melalui program CSR yang telah dilaksanakan, yaitu: Aqua mendapat penghargaan Gold pada KSN (Kesetiakawanan Sosial Nasional) Awards 2010 yang diselenggarakan oleh Kementrian Sosial dan CFCD (Corporate For Community Development Program) Program penanaman kembali hutan Gunung Klabat, Minahasa Utara dimana DANONE AQUA Sulawesi Utara mendapatkan penghargaan Wana Lestari dari Departemen Kehutanan Republik Indonesia DANONE AQUA berhasil meraih penghargaan MDGs (Millenium Development Goals) dari Perserikatan Bangsa-Bangsa dan Metro TV dalam kategori pelestarian lingkungan (environmental sustainability) atas program WASH (water access, sanitation and hygiene).

Menurut penulis, kesuksesan program-program CSR yang dilakukan oleh Aqua tidak terlepas dari faktor kredibilitas perusahaan yang telah menjadi salah satu perusahaan penghasil air mineral terkemuka di Indonesia sehingga memiliki profit keuangan yang cukup besar. Dengan profit keuangan yang cukup besar tersebut, Aqua berani mengeluarkan anggaran untuk CSR hingga mencapai angka 12 Miliyar Rupiah per tahun. Didalam menjalankan program-program CSR nya, Aqua pun bekerjasama dengan berbagai lapisan masyarakat, LSM, dan oraganisasi pemerintah sehingga proses pelaksanaan program CSR tersebut dapat terpantau oleh seluruh golongan. Tidak hanya sampai disitu, Aqua pun didalam melaksanakan program-program CSR nya selalu mengutamakan aspek yang berkelanjutan. Dimana setiap program CSR yang telah dilaksanakan dipantau perkembangan dan tingkat keberhasilannya, kemudian program tersebut dilakukan secara continue dan berkesinambungan sehingga tidak hanya sekedar membahagiakan masyarakat secara instant dan sekejap. Keseluruh hal tersebut menimbulkan pencitraan yang baik bagi Aqua selaku perusahaan air mineral terkemuka di Indonesia. Jika ditinjau berdasarkan salah satu prinsip CSR yaitu "Triple Bottom Lines", dimana perusahaan harus memperhatikan tiga unsur penting diantaranya: Profit (Perusahaan tetap harus berorientasi untuk mencari keuntungan 


\begin{tabular}{rlrr}
\hline \hline Volume: & 2 & E-ISSN: & $2655-1942$ \\
Number: & 2 & Terbitan: & Oktober 2019 \\
Page : & $118-134$ & & \\
\hline
\end{tabular}

ekonomi yang memungkinkan untuk terus beroperasi dan berkembang) People (Perusahaan harus memiliki kepedulian terhadap kesejahteraan manusia) Planet (Perusahaan peduli terhadap lingkungan hayati. Beberapa program CSR yang berpijak pada prinsip ini biasanya berupa penghijauan hidup lingkungan hidup) Tentu jika kita memperhatikan pemaparan pada contoh-contoh kasus didalam makalah ini, tentu kita akan sepakat bahwa Aqua telah memenuhi ketiga unsur didalam prinsip Triple Bottom Lines CSR karya Carrol tersebut.

\section{Kesimpulan}

CSR adalah operasi bisnis yang berkomitmen tidak hanya untuk meningkatkan keuntungan perusahaan secara finansial, tetapi untuk pembangunan sosial-ekonomi kawasan secara holistik, melembaga, dan berkelanjutan. Beberapa nama lain yang memiliki kemiripan dan bahkan sering diidentikkan dengan CSR adalah corporate giving, corporate philanthropy, corporate community relations, dan community development. Setidaknya ada 2 (dua) landasan berkenaan dengan corporate social responsibility (CSR) yaitu berasal dari etika bisnis (bisa berdasarkan agama, budaya atau etika kebaikan lainnya) dan dimensi sosial dari aktivitas bisnis. CSR atau sering diartikan sebagai "being socially responsible" jelas merupakan suatu cara-cara yang berbeda untuk orang yang berbeda dalam negara yang berbeda pula. Artinya penerapan CSR di masing-masing negara harus disesuaikan dengan konteks sosial dan lingkungannya. Sehingga perlu kehati-hatian dalam menerapkan konsep CSR dari negara-negara maju di negara-negara yang sedang berkembang

Tanggungjawab sosial perusahaan atau Corporate Social Responsibility (CSR), diatur secara tegas di Indonesia, dalam Undang-Undang Nomor 40 Tahun 2007 tentang Perseroan Terbatas, terdapat empat alasan hukum mengenai perlunya CSR diatur dalam Perundang undangan di Indonesia. Ke empat alasan tersebut adalah alasan filosofis, yuridis, sosiologis dan historis. Indonesia termasuk negara yang menjalankan penerapan tanggung jawab sosial perusahaan dengan pendekatan implisit. Isu mengenai tanggung jawab sosial perusahaan (corporate social responsibility) diatur dalam suatu peraturan perundang-undangan. Maka, tanggung jawab sosial perusahaan (corporate social responsibility) dapat dilakukan dengan beragam pendekatan, baik yang sifatnya sukarela maupun wajib atau mandatory dari pemerintah. 


\begin{tabular}{llrr}
\hline \hline Volume: & 2 & E-ISSN: & $2655-1942$ \\
Number: & 2 & Terbitan: & Oktober 2019 \\
Page $: 118-134$ & & \\
\hline
\end{tabular}

\section{DAFTAR PUSTAKA}

\section{A. Buku}

Ely Kusumardani. 2016. Tinjauan Yuridis Corporate Social Responsibility (CSR)

Menurut Undang-Undang Nomor 40 Tahun 2007 Tentang Perseroan

Terbatas, Surakarta: UMS

Hendrik Budi Untung. 2008. Corporate Social Responsbility, Jakarta: Sinar Grafika

Bayu Gabriel, 2017, "CSR Sebagai Bentuk Komunikasi Kesehatan dan Lingkungan" ,Jakarta: Sinar Grafika

Meilanny Budiarti S, Santoso Tri Raharjo. 2014. Corporate Social Responsibility (Csr)

Dari Sudut Pandang Perusahaan

Subari. 2014. Corporate Social Responsibility, diakses melalui http://subaripemuda.blogspot.com/2015/01/makalah-tentang-corporatesocial.html

Sadi, Is, Muhammad, 2016, Hukum Perusahaan di Indonesia,Jakarta, Kencana Prenamedia, hal.231.

Rahmatullah, 2017, Buku Pintar CSR, Jakarta, Samudra Biru, hal.128.

Priyono, Ery Agus, Bahan Kuliah Metodologi Penelitian, Program Studi Magister Kenotariatan Universitas Diponegoro, Semarang, 2003/2004

\section{B. Jurnal}

Pujiyono, Jamal Wiwoho, Triyanto, "Model Pertanggunganjawaban Hukum Pelaksanaan Corporate Social Responsibility (CSR) Untuk Meningkatkan Kesejahteraan Masyarakat”, Yustisia Jurnal, Vol.5,No.1, April 2016

Sefriani,Sri Wartini, "Model Kebijakan Hukum Tanggung Jawab Sossial Perusahaan di Indonesia”, JH Ius Quia Iustum FH UII, Vol.26,Januari 2017. 


\begin{tabular}{llrr}
\hline \hline Volume: & 2 & E-ISSN: & $2655-1942$ \\
Number: & 2 & Terbitan: & Oktober 2019 \\
Page : $118-134$ & & \\
\hline
\end{tabular}

Sumiyati, Y., 2013. Peranan BUMN dalam Pelaksanaan Tanggung Jawab Sosial Perusahaan untuk Meningkatkan Kesejahteraan Rakyat. Jurnal Fakultas Hukum UII, 20(3), pp.460-481.

Mhd, Bahlian, "Pengaruh Corporate Social Responsbility Dalam Meningkatkan Penanaman Modal Asing", Jurnal Hukum Samudra keadilan, FH Universitas Samudra, Vol.12,No.1, Juni 2017.

Ade Yuliany Siahaan, Suhaidi, Sunarmi, Jelly Leviza, "Analisis Yuridis Atas Peran Pemerintah Terhadap Pelaksanaan Tanggung Jawab Sosial Perusahaan”, USU Law Jurnal, Vol.6, No.3, April 2018.

Dewa Ayu Putu Shandra Dewi,I Nyoman Nurjana,Sihabudin "Kewajiban Hukum Tanggung Jawab Sosial Perusahaan (CSR) Dalam Peraturan PerundangUnadangan di Indonesia”, Jurnal Magister Kenotariatan Fakultas Brawijaya, diakses 20 September 2019.

\section{Website}

http://subaripemuda.blogspot.com/2015/01/makalah-tentang-corporate social.html pada 12 Agustus 2019)

https://id.wikipedia.org/wiki/Tanggung jawab sosial perusahaan pada 12 Agustus $\underline{2019)}$

https://www.kompasiana.com pada 13 Agustus 2019) 